\title{
Determinants of Access to Finance among Manufacturing Micro, Small and Medium Enterprises in Nigeria
}

Bello, O.F. ${ }^{1}$, Mustapha, Y.I. ${ }^{2}$

${ }^{1}$ Department of Economic, State College of Education, Oro, Kwara State.

${ }^{2}$ Department of Marketing, University of Ilorin, Ilorin, Nigeria.

${ }^{1}$ fatbell03@yahoo.com, ${ }^{2}$ ismyoriss@gmail.com

\begin{abstract}
This study investigates the determinants of access to finance among manufacturing micro, small and medium enterprises in Nigeria (MSMEs). This study uses the Nigeria enterprise survey dataset conducted by the World Bank between April, 2014 and February, 2015. A robust logistic regression model has been applied for a sample of 507 manufacturing MSMEs in Nigeria to achieve this study's objective. The results indicate that access to finance is largely influenced by owner/managers' experience and owner/managers' skills. By implication, owners'/managers' experience and skills are the driving force for manufacturing MSMEs' probability of having access to finance in Nigeria. Therefore, this study recommends that owners/managers of MSMEs in Nigeria should leverage their stock of experience and innate skills to enhance their firms' access to finance.
\end{abstract}

Keywords: Finance, Access to Finance, Micro, Small and Medium Enterprises, Owner/Managers’ Experience, Owner/Managers’ Skill

Copyright: (C) 2021 Bello, O.F., Mustapha, Y.I. This is an open access article distributed under the Creative Commons Attribution License, which permits unrestricted use, distribution, and reproduction in any medium, provided the original work is properly cited.

Correspondence: fatbell03@yahoo.com

ORCID of authors: Mustapha, Y.I. - (D) https://orcid.org/0000-0002-6303-0536

DOI: http://doi.org/10.4038/kjm.v10i1.7627 


\section{Introduction}

In almost all world economies, especially in developing countries of Africa like Nigeria, micro, small and medium enterprises (MSMEs) are generally regarded as the driving force behind economic growth, job creation, and poverty reduction. Apart from the fact that they contribute to the increase in per capita income and output, they also encourage the development of indigenous entrepreneurship, enhance regional economic balance and generously promote effective resource utilization that is considered critical in the area of engineering economic development (Akpotohw, 2007; Hamid \& Bello, 2008; Kwaido, 2009; Chowdhury \& Alam, 2017). Policy makers have also recognized micro, small and medium enterprises as important mechanisms for growth as they represent the vast majority of all enterprises (OECD, 2005; Kraemer-Mbula, Lorenz, TakalaGreenish, Jegede, Garba, Mutambala, \& Esemu, 2019). In fact, in her (2017) group report, World Bank further affirmed the above position. It asserted that MSMEs play a critical role in creating job opportunities and perform other exceedingly important functions such as supporting innovation and diversification and beyond.

In Nigeria, micro, small and medium enterprises with a total number 37.07 million accounts for about 50 percent of industrial jobs and nearly 90 percent of the manufacturing sector (Obitayo, 1991). They are the main engine of economic growth and a major factor in promoting private sector development and partnership (Obitayo, 1991). Despite these remarkable important functions being performed by MSMEs in every nation's economic system, many of these MSMEs do not survive their first year of operations in business (Akande \& Ojokuku, 2008; Raji, 2018; Essien \& Arene, 2005). Consequently, many of the MSMEs do not provide the needed benefits to society. According to the World Bank Group report (2017), these MSMEs are generally ostensibly perceived as risky by most banks and other financial institutions. Access to finance is a significant factor limiting their capacities to fully play their roles in supporting economic growth and development and creating job opportunities. Akande and Ojokuku (2008) further maintained that a number of scholars had identified inadequate access to finance as a major bottleneck limiting the sizes, growths, profits, scopes, and operational activities of MSMEs. For instance, the access to finance of vast majority of MSMEs in Nigeria has become very inadequate and unpredictable, and these may have affected their growths and successes. The issue of access to credit facilities is a critical problem confronting MSMEs operations in Nigeria. Confirming this situation, Harvie and Lee (2008) asserted that lack of adequate capital or financial resources served as a major barrier to MSMEs owners' success because these entrepreneurs usually mobilize their resources to establish or expand their businesses. Moreover, Harvie and Lee (2008) observed that manufacturing micro, small and medium enterprises in developing countries have difficulties accessing bank loans due to the high risk involved in loan repayment, low level of profitability, and lack of collateral required by banks.

The difficulties faced by MSMEs in getting the required finance have been discussed among the owners of MSMEs, the banks, the academia, the researchers, and the government. In Nigeria, various government reform strategies such as Central Bank's MSME development fund (single-digit interest rate of 9\%), Bank of Industry Funds for Start-up and MSMEs etc. which are meant to promote growth and development of MSMEs have not yielded fruitful results and the extant financing gap is still large (Akande \& Ojokuku, 2008; Raji, 2018).

The study on the determinants of access to finance among MSMEs has received great attention from researchers and policymakers 
worldwide, with each examining different aspects of the subject matter. For instance, Zeller (1994) studied informal lenders and formal credit groups in Madagascar, while Falk (2008) examined the factors influencing access to finance in the rural area of Myanmar. Studies (such as Gamage 2013; Kuranja, Nwaugi and Nyakarimi 2014; Ganzalo, Lopes \& Sauna 2007) have also investigated the determinants of small and medium-sized enterprise access to bank finance. In Nigeria, Filli, Onu, Adebayo, and Tizhe (2015) investigated the factors that influence access to credit facilities among small-scale fish farmers in Adamawa State, Nigeria. Similarly, Essien and Arene (2014) conducted a study that analysed access to credit markets and small-scale agro-based enterprises' performance in the Niger Delta Region of Nigeria. However, these studies' findings are at variance with each other, suggesting that the investigation into the determinants of access to finance among manufacturing MSMEs is inconclusive. Hence, the interest of the current study stems from this noticeable gap.

The review of extant related literature on the determinants of access to finance( such as Essien and Arene, 2014; Gamage 2013; Akande and Ojokuku, 2008 and Raji, 2018) further indicated that factors such as ownership type, the age of the firm, sector of operation, location of business, asset tangibility, firm performance, availability of audited financial statements, gender of the owner/manager, experience of the owner/manager and the owner's/manager's perception of their access to finance, among others are likely to influence MSMEs access to finance.

The literature surveyed also indicates that most of the studies (such as, Zeller 1994; Ganzalo, Lopes \& Sauna 2007; Gamage

2013; Leitner \& Stehrer 2013; Harvie, Narjoko \& Oum 2013; Afandi \& Kerman 2014) have been conducted to understand the determinants of access to finance among manufacturing micro, small and medium enterprises in western world, middle and far east with very little empirical evidence noticeable in Africa and by extension Nigeria. Therefore, the findings and policies from other regions of the world cannot be generalized and applied to Sub-Sahara African countries like Nigeria because of peculiarities of each region of the world. In addition, the very few studies carried out in this part of the world were on a particular state or area in the country; therefore, there is need for further studies with wider coverage and scope. In view of all these, this paper aims to fill these obvious gaps and contribute to the debate by investigating the determinants of access to finance among micro, small and medium manufacturing enterprises in Nigeria.

By attempting to address some of the weaknesses of some of the empirical studies reviewed in this work, the findings of this study would have some practical significance on micro, small and medium enterprises industry of Nigeria economy. For instance, for entrepreneurs/business owners, the outcome of the study will enhance their understanding of the determinants of MSMEs access to finance in Nigeria and this may add value to their knowledge on financial business decisions. Also, the study's insightful findings will be useful in stimulating public discourse given the dearth of empirical studies in this area from emerging economies like Nigeria.

This paper has been divided into six sections. This section apart, section 2 deals with literature review, section 3 dwells on methodology, section 4 deals with results and discussions, section 5 concludes the paper.

\section{Literature Review}

The definition of micro, small, and medium enterprises is usually based on several criteria that vary over time and across 
geographical locations. Different writers, both academics and policymakers, have attempted to define MSMEs from different perspectives. In some countries, the company's turnover is used to determine an enterprise's size, while some use fixed investment or number of employees (World Bank 2014; Kraemer-Mbula et al. 2019; Akande and Ojukuku, 2008). In Nigeria, the National Policy on MSMEs adopts a classification based on dual criteria of employment and assets (excluding land and buildings). For instance, Small and Medium Enterprises Development Agency of Nigeria (SMEDAN, 2012) sees micro enterprise as any enterprises with assets excluding land and building to be less than N5M with less than 10 employees. In addition, small enterprises are seen as any enterprises with assets excluding land and building to be less than N50M with less than 49 employees and medium enterprises as any enterprises with assets excluding land and building to be less than N500M with less than 199 employees.

The survey of existing literature such as Kraemer-Mbula et al. (2019) and Akande and Ojukuku (2008) revealed that most of the definitions in use depend on the purposes for which those definitions are required to serve and the policies which govern the MSMEs sector. However, for this study's purpose, the World Bank (2014) definition in conducting the survey, the dataset of which this study has applied, is adopted. The World Bank (2014) defines a micro-enterprise as any enterprise with less than five employees, a small enterprise with between 5 and 19 employees; and medium enterprise with between 20 and 99 employees. These definitions were adopted for this study because the dataset were collected based on these classifications.

\section{Theoretical framework}

Access to finance has been linked to some theories, including credit rationing theory, information asymmetry theory, transaction costs theory, and market failure theory. However, this study adopted the theoretical perspectives from two very common and prominent theories of capital structure of the firms. The theories are credit rationing and information asymmetry.

One of the most important theories that focus on financing gap analysis is the credit rationing theory by Stiglitz and Weiss (1981). According to Stiglitz and Weiss (1981), credit rationing is when the lender denies credit to the borrowers who want funds and are willing to pay a higher interest rate. It is an example of market imperfection or market failure. In their formulation, Stiglitz and Weiss (1981) posited that credit rationing can be an equilibrium feature of the market in the sense that the rationed borrower would be willing to obtain the fund at an interest rate higher than the one charged by the lender, who will not be willing to lend the extra funds, as the higher rate would imply lower expected profit.

According to Stiglitz and Weiss (1981), three measures can be adopted to address the shortage of institutional credit available for the business sector. Firstly, charging a higher and progressive interest rate on the loan amount after a specific limit; secondly, imposing an upper limit in the credit available to the big firms or industries; and thirdly, offering credit to the weaker sectors at a lower interest rate. It is evident that credit rationing results not necessarily due to a credit shortage but due to asymmetric information.

Since the seminal contribution of Akerlof (1970), the pervasive effects of information asymmetry in markets have been documented as studied in numerous contexts. Information asymmetry theory deals with the study of the decision in transactions where one party has more or better information. According to Akerlof (1970), in many markets, the seller uses some market statistics to measure his selling value. In this context of the credit market, the buyer sees the average prices of the loans in the market he intends to buy while the seller has a more intimate knowledge of 
each, and specific loan produced. This puts the seller at a more advantage, thus selling goods of less than average market quality. However, the limitation of the information available to the buyer may lead to a reduction in size of the market. Therefore, information asymmetry theory assumes that at least one party to a transaction has relevant information, whereas the other does not. Thus, asymmetry creates an imbalance of power in transactions which can cause market failure. Examples of these problems are adverse selection, monopolies of knowledge, and moral hazard.

According to Gamage (2013), the bank's credit rationing behavior may theoretically be influenced by several factors which include the borrower's observable characteristics (age, gender, wealth, experience, credit history), firm characteristics (business experience, risk profile, earnings), and loan characteristics (amount demanded, loan maturity, collateral offered, interest rate). Stiglitz and Weiss (1981) explained the choice among different financing sources under asymmetric information and credit rationing conditions. Some categories of MSMEs will face additional problems due to lack of security, such as young entrepreneurs or those from deprived areas. Also, the practice of credit rationing by financial institutions using interest rates has locked out most poor individuals as only large-scale borrowers who expect higher returns can bear the high cost of borrowing (Stiglitz \& Weiss, 1981).

In this study, credit rationing theory has been adopted to formulate the important factors influencing access to finance among MSMEs. This is because bank and non-bank financial institutions are concerned about lending money to MSMEs operators who are not likely to default after taking the loan.

\section{Review of Empirical Literature}

Some of the factors influencing access to finance based on the literature reviewed (Zeller, 1994; Gamage 2013; Essien and
Arene 2014; Fillis et al. 2015) include gender of owner/manager of an enterprise, experience of the owner/manager, an enterprise's age, an enterprise owner's/manager's skill, and the extent of foreign ownership. Some studies have been conducted on the relationship between gender and access to finance, but the studies' findings are mixed.

Filli et al. (2015) investigated factors influencing credit access among small-scale fish farmers in Adamawa, Nigeria, using a cross-sectional dataset for a sample of 220 respondents. The results of the linear probability regression indicated that gender has no significant influence on access to finance. Similarly, Zeller (1994) studied informal lenders and formal credit groups in Madagascar, using a cross-sectional dataset for a sample of 230 respondents by applying a univariate probit model. The results revealed that gender is not a significant factor in determining access to credit. This indicates that gender has no significant influence on access to credit.

However, contrary to the studies of Fillis et al. (2015) and Zeller (1994), Kaino (2005) used a cross-sectional dataset for a sample of 115 respondents to examine the factors influencing access to finance in a rural area of Myanmar by applying binary logistic regression model. The outcome of the study shows a significant positive influence of gender on access to finance. In a related work, Sebopetji and Belete (2009) used a cross-sectional dataset for a sample of 173 SMEs farmers in greater Letaba local municipality in South Africa. The binary probit regression analysis results indicated that gender has a significant positive influence on access to finance. In the same vein, Kuranja et al. (2014) identified the factors influencing access to credit among women entrepreneurs in Kenya using crosssectional dataset from a sample of 38 enterprises by applying chi-square in testing the hypothesis, the results of the analysis revealed that gender of the owner of an 
enterprise is positive and has a significant influence on access to finance.

Another factor influencing access to finance is the age of an enterprise. An enterprise's age appears in several empirical finance literature studies as a control variable, especially in corporate strategy research (Villalonga, 2014). Empirical findings from previous studies (such as Martins and Daniel 2013; Gamage 2013; Essien and Arene 2014) suggested that some MSMEs exhibit certain characteristics which make them more likely to fail to secure the funding they need. Aryeetey, Baah-Nuakoh, Duggleby, Hettige, and Steel (1994) used a crosssectional dataset for a sample of 133 MSMEs in Ghana by applying simple percentages and Pearson correlation analysis. The results of the study revealed a significant positive correlation between enterprise age and access to bank finance. In the same vein, North, Robert, and Ignatius (2010) also find a significant positive correlation between firm age and access to bank finance using a cross-sectional dataset by applying Pearson correlation coefficient for a sample of 1014 Scottish SMEs.

It is evident from the review that being in the business for many years suggests that a firm is competitive in general and more transparent. The information required by the lenders to evaluate and process applications are readily available. Moreover, new firms are not likely to meet the banks' collateral requirements since they have not accumulated sufficient assets. Ganzalo, Lopes, and Saunna (2007) investigated access by Spanish firms to external financing using dynamic panel data estimation technique over a sample of 60,000 Spanish firms during the period from 1992 to 2002. The results of the ordinary least squares revealed that age of the enterprise has a significant positive influence on MSMEs access to finance. In a related study, Martins and Daniel (2013) examined the influence of firms' profile on access to finance among Small and medium enterprises in Kenya using a cross-sectional dataset for a sample of 103 SMEs. Ordinary least square regression analysis was employed as analytical technique. The results of the study shown that the age of the enterprise indeed influences SMEs access to finance.

In contrast, Gamage (2013) uses the enterprise survey cross-sectional dataset of Sri Lanka for a sample of 610 enterprises from the World Bank. The result of the logistic regression analysis indicated that the enterprise's age does not appear to have any significant influence on the probability of having access to finance.

Some studies have found that one of the criteria for successful MSMEs is the level of experience of the owner/manager (Kira, 2013; Ayalew \& Gashu, 2015). Entrepreneur experience has been recognised as an asset in accessing banks' financial facilities (Politis, 2008). Lenders emphasize the importance of the experience of the owner/manager at the time of lending assessment. They may look favourably to loan applicants with more business experience than an inexperienced applicant who may be riskier to the banks. For example, Ayalew and Gashu (2015) conducted a study using a cross-sectional dataset for a sample of 219 micro and small enterprises in Dilla town in Ethiopia. The ordinary least squares results indicated a significant negative relationship between lack of experience by the owners or the manager and access to bank loans. This simply shows that owners/manager experience has a significant positive influence on firm access to finance.

In a study conducted by Kira (2013) on ascertaining the determinants of SMEs access to debt financing in Tanzania via a cross-sectional dataset sample of 164 firms and applying logistic regression as a statistical tool of analysis. The study results revealed a significant positive influence of owners'/managers' experience on firm access to finance. On the contrary, Mersha and Zenhun (2017) examined the determinants of access to formal financial 
sources of MSMEs in the West Oromia region of Ethiopia using a cross-sectional dataset for a sample of 200 MSMEs and applying a binary logit model. The results shown that the owners' or managers' experience is not found to determine access to bank credit. In a related study, Gamage (2013) also evaluated the determinants of access to bank finance for small and medium-sized enterprises using a crosssectional dataset for a sample of 610 enterprises obtained from Sri Lanka enterprise survey conducted by World Bank. The study's finding revealed that owners'/managers' experience is unlikely to influence access to finance. Leitner and Stehrer (2013) also used a panel dataset for a sample of 10,930 Latin American enterprises and 9,536 Caribbean enterprises from year 2006 to 2010 and applied logistic regression model as analytical tool. The study found that foreign owners/managers are significantly more likely to access finance.

Harvie, Narjoko, and Oum (2013) investigated small and medium enterprises' access to finance from selected Asian Economies. The logistic regression analysis results on a cross-sectional dataset for a sample of 1,055 firms indicated that foreign ownership is an important factor in determining access to finance. Similarly, Afandi and Kerman (2014) examined financing obstacles of Bangladesh firms using a cross-sectional dataset for a sample of 1,500 firms and utilized ordinary least squares regression analysis as an analytical technique. The results revealed that foreign ownership has a significant positive influence on access to finance.

Furthermore, Beck, Dermirguc-kunt, Laeven, and Maksimovic (2006) used a cross-sectional dataset for a sample of 10,000 firms from 80 Asian countries and used a logistic regression model to analyse the data. The results showed that foreign ownership is significantly and positively related to the probability of having access to finance. Zarook, Rahman, and Khenam
(2013) surveyed management skills and access to finance of SMEs in Libya using a cross-sectional dataset of 557 SMEs as sample and ANOVA was used to analysis the data. The study results indicated a significant difference between enterprises with high management skills and those without access to formal finance.

In a study conducted by Essien and Arene (2014) on access to credit markets and the performance of small-scale agro-based enterprises in the Niger Delta Region of Nigeria using a cross-sectional dataset for a sample of 96 small-scale entrepreneurs. The logistic regression results revealed that owners' skill is significantly and positively related to the probability of having access to finance. This indicates that the higher the level of education of the owner of MSMEs, the more enlightened they are and the more likely they are to access credit.

In contrast, Ogubazghi and Muturi (2014) investigated the effect of the educational level of owner/manager on access to a loan in Asmara city, Eritrea, using a crosssectional dataset for a sample of 87 small and medium enterprises. The logistic regression analysis result shown that the owner/manager's educational level does not have a significant effect on access to formal finance.

\section{Development of Hypotheses}

In line with the stated objectives of the study and in agreement with the conceptual issue, extant literature and theories reviewed, the study proposed the following hypotheses:

$\mathrm{H}_{01}$ : Gender of owner/manager is not likely to have any significant effect on access to finance of MSMEs.

$\mathrm{H}_{02}$ : $\quad$ The age of an enterprise is unlikely to have any significant influence on MSMEs' access to finance.

$\mathrm{H}_{03}$ : Owner/manager skills are not likely to have any significant influence on MSMEs' access to finance.

$\mathrm{H}_{04}$ : Experience of top manager/owner of 
the enterprise is unlikely to have any significant influence on MSMEs’ access to finance.

\section{Methodology}

This section deals with the type and kind of data and data analysis method employed in carrying out this study.

\section{Data}

This study uses the Nigeria Enterprise Survey cross-sectional dataset conducted by the World Bank between April, 2014 and February, 2015. The enterprise survey collected a wide range of quantitative and qualitative information through face-to-face interviews with firm managers and owners on their firms' productivity and business environment. The survey uses a standardized instrument of a survey and a consistent, uniform sampling method to abate the instances of measurement error and produce datasets that will be usable and acceptable across different world economies.

\section{Sample Size and Sampling Technique}

The sampling technique applied for the Nigeria Enterprise Survey was stratified sampling as part of a probability sampling method. Four levels of stratification were used, that is, by sector of activity, by the size of the economy as measured by Gross National Income (GNI), by enterprise size based on several employees, and by geographical location based on the distribution of non-agricultural economic activity of the country. The survey got its sampling frames using data compiled from the National Bureau of Statistics (NBS) and local and municipal business registers.

The manufacturing sector in Nigeria is the primary sector of interest for this study because it is still the largest sector in terms of export, innovation, and productivity growth (Manyinka \& Sinclair, 2012). The manufacturing questionnaire was administered to owners/managers of enterprises through a face-to-face interview.
The dataset consists of 2,676 enterprises. Having dropped the missing values, a total number of 507 enterprises were found to complete dataset for this study.

\section{Variables Measurement}

The variables of interest that were measured in this study are:

i. Access to finance: This variable was measured as a dummy variable, taking a value of 1 if an enterprise has access to sources of finance to fund its business and 0 if otherwise. This is adapted from the work of Mustapha, Anafi and Gbadeyan (2014) and Oum, Narjoko, and Harvie (2014).

ii. Gender of owner/manager: This was measured as a dummy variable, taking a value of 1 for a male owner/manager and 0 otherwise. This measurement has been adopted from the work of Gamage (2013) and Mustapha, Anafi and Gbadeyan (2014).

iii. Age of an enterprise: This was measured as a natural logarithm of the number of years since the enterprise began operating in the country. This is adapted from the work of Marques and Ferreira (2009).

iv. Owner/manager experience: Years of experience as owner/manager in the business. This is adapted from the work of Gamage (2013).

v. Owner/manager skill: This was also measured as a dummy, taking a value of 1 if the owner/manager holds a minimum of first degree or HND and 0 otherwise. This has been borrowed from the work of Lieponen (2005).

vi. Foreign ownership: A foreign-owned enterprise was measured as a dummy variable, taking a value of 1 if it reports that a foreign company owns at least $50 \%$ of its capital and 0 otherwise. The measurement of this 
variable has been adopted from the work of Oum et al. (2014).

\section{Method of Data Analysis}

Descriptive and inferential statistical methods were used in the analysis of the data collected for this study. Dataset has been summarised using descriptive statistics in the form of mean, minimum, and maximum to meaningfully describe the dataset's true nature.

Access to finance as a dependent variable was measured as a dummy variable in the model, categorical dependent variable estimator in the form of Logistic regression adapted to analysis the data to determine the relationship among owner's/manager's gender, owner's/manager's experience, owner's/manager's skill, enterprise age, the extent of foreign ownership, and access to finance (dependent variable).

\section{Model specification}

The logistic regression model was used as an analytical technique due to its generic application, versatile nature, and appropriate interpretation for the explanatory variables' effect (Hailperm \& Visintainer, 2003). The data was run using Stata statistical software version 14. The empirical specification of the model employed in this study is as follows:

Acfin $_{i}=\beta_{0}+\beta_{i}$ Ownerexp $_{i}+\beta_{2}$ Entpage $_{i}+\beta_{3}$ Gendummy $_{\mathrm{i}}+\beta_{4}$ ownskill $_{\mathrm{i}}+\beta_{5}$ foreinown $_{\mathrm{i}}$ $\mu_{\mathrm{i} \ldots \ldots .1}$

Where:

\begin{tabular}{|c|c|}
\hline $\operatorname{Acfin}_{i}$ & $\begin{aligned}= & \text { Access to finance (treated as } \\
& \text { a dummy variable) }\end{aligned}$ \\
\hline Ownerexp = & $\begin{aligned}= & \text { Experience of the } \\
& \text { owner } / \text { manager }\end{aligned}$ \\
\hline Entpage $_{i}$ & $=$ Enterprise age \\
\hline Gendummy & $y_{i}=$ Gender of owner/manager \\
\hline Ownskill & = Owner's/manager's skill \\
\hline $\begin{array}{l}\text { Foreinown } \\
=\text { Parameter }\end{array}$ & $\begin{array}{l}=\text { Extent of foreign ownership } \beta \\
\text { rs }\end{array}$ \\
\hline & $=$ Error term \\
\hline
\end{tabular}

\section{Results and Discussions}

\section{Descriptive Results}

This subsection presents the descriptive results for quantitative and qualitative variables of the study.

Table 1 (Appendix A) presents the results of the descriptive analysis of the quantitative variables used in the model in the form of mean, minimum and maximum. However, the total number of observations covered in the study was 507 enterprises. In this study the number of years since the enterprise began operation was used as a proxy for enterprise age. The result indicated that that the mean of enterprise age stood at 14.5 with a minimum of 0 and maximum of 64 years. This indicated that while some of the enterprises have been in existence for the past 64 years, some of them were not up to a year in existence.

Also, from the results in table 1 (Appendix A), the number of years of working experience was used as a proxy for owners'/managers' experience. The mean year of experience stood at 13.06 years with a minimum of 1 and a maximum of 54 years. This indicated that some owners of the enterprises had 1 year working experience while some of them had up to 54 years working experience.

Table 2 (Appendix B) presents the results of qualitative descriptive analysis of this study. The results indicated that 53 of the enterprises, representing $10.45 \%$ of the sample had access to finance. These findings suggest low level of access to finance among MSMES in Nigeria and therefore call for policy direction towards facilitating easy access to credit for MSMES operators in Nigeria.

For the owner/manager skills, 141 of the enterprises, representing $27.81 \%$ of the sample had their owners/managers having a degree/HND and above qualification. Therefore, the results indicated only a small 
proportion of the owners/managers possessed higher educational qualification.

The descriptive analysis also revealed that 58 of the enterprises, representing $11.44 \%$ of the sample have had their owners/managers as females. The results therefore indicated females are underrepresented in the management of MSMEs in Nigeria. However, only 6 enterprises, representing $1.8 \%$ of the sample had foreign ownership, indicating that only small proportion of the enterprises were owned by foreigners.

\section{Inferential Results}

Table 3 (Appendix C) presents the results of robust logistic regression. From the results of the robust logistic regression, the Wald Chi-square indicates that the model is statistically significant at $10 \%$ level. The coefficient of owners'/managers' experience is positive and statistically significant at $5 \%$ level. The positive sign of this variable indicates that the enterprises having owners/managers with more experience are more likely to have access to finance than those having their owners/managers with less experience.

Specifically, a unit increase in an owner's/manager's experience is more likely to increase the expected log odds of manufacturing MSMEs access to finance by 1.03. This suggests that manufacturing MSMEs' access to finance can be stimulated by the accumulation of owners/mangers' experience. This finding provides empirical support for the works of Ayalew and Gashu (2015) and Kira (2013), while it refuted that of Mersha and Ayanew (2017) and Gamage (2013).

It could also be drawn from the results of the model that the skill of the owner/manager of an enterprise is statistically significant at 5\% level. The positive sign of the coefficient indicates that an enterprise with owner/manager who has higher skill is more likely to have access to finance than the one with owner/manager having little or no skill at all. Statistically, for a unit increase in the skill of an owner/manager of an enterprise, the expected log odds of access to finance increase by 2.03. This suggests that the owner's/manager's experience is a driving force for manufacturing MSMEs probability of having access to finance in Nigeria.

However, the rest of the variables, enterprise age and its squared value, the extent of foreign ownership, and owner's/manager's gender, are unlikely to influence the probability of having access to finance by manufacturing MSMEs in Nigeria as indicated by their low odds ratios and pvalues.

\section{Discussion of results}

This study's first objective explored the influence of owners'/managers' gender on MSMEs access to finance. The regression analysis results revealed that the owner's/manager's gender did not positively and significantly influenced MSMEs' access to finance. This result supports the findings of Zeller (1994) and Fillis et al. (2015) that revealed that gender has no significant influence on MSMEs access to finance. However, this result is contrary to the findings of Kaino (2005) and Sebopetji and Belete (2009) that found that gender has a significant positive influence on MSMEs' access to finance.

The second objective of this study determined how the age of MSMEs affects their access to finance. This study's finding indicated that age of an enterprise is not positive and statistically significant to MSMEs access to finance. This result is consistent with the finding of Gamage (2013) that discovered that the enterprise's age does not have any significant influence on the probability of small and mediumsized enterprises having access to finance. However, this result contradicts the finding of Ganzallo et al. (2007) that age of the enterprise has a significant positive influence on MSMEs access to finance. 
The third objective of this study examined the influence of owner's/manager's skills on MSMEs access to finance. It was discovered from the study results that owner's/ manager's skills have significant positive relationship with MSMEs access to finance. This confirms the findings of previous studies such as Ogubazghi and Muturi (2014), which discovered a relationship between the extent of owner's/ manager's qualification and MSMEs access to finance. However, this study's finding is contrary to the findings of Essien and Arene (2014), which discovered that highly skilled owners/ managers are less likely to increase MSMEs access to finance.

Finally, the fourth objective of this study is the influence of the owner's/ manager's experience on access to finance. From the study's findings, the owner's/ manager's experience is found to be statistically significant and positively related to access to finance. This finding is in line with previous studies such as Ayalew and Gashu (2015) and Kira (2013), which also found a significant positive influence between owners/manager's experience and firm access to finance. However, the finding of the current study has contradicted the result of Mersha and Zenhun (2017) studies and Gamage (2013) that discovered that owners'/managers' experience is unlikely to influence firms' access to finance.

\section{Conclusion and Recommendations}

The following conclusions were drawn from the inferential statistical analysis of this study; that gender and age of the owner's/manager's did not positively and significantly influence MSMEs access to finance. It is also concluded that the owner's/ manager's skills and experience have a significant positive relationship on MSMEs access to finance.

Based on the above conclusions, the following recommendations were made to aid MSMEs owners/managers in making decisions regarding their firms' access to formal forms of finance.

i. It has been scientifically proven that the owner's/ manager's skills and experience influence MSMEs' access to finance. MSMEs operators (i.e. owners/ managers) should leverage on the skills and stock of experience they have garnered over the years to enhance their firms' accessibility to formal sources of finance.

ii. MSMEs owners/managers should try to avoid projecting their age and gender when sourcing for access to finance because it has been statistically shown that the two do not influence MSMEs access to finance.

\section{Suggestions for further studies}

This study is limited in scope in terms of the sector and the number of variables examined. Hence, further studies should address other sectors of the economy and other variables such as the firm's profit, owners' marital status, owners age, and competition which are not captured in this study to expand the frontier of knowledge. Further studies should also be carried out on service industry. This study is only conducted in Nigeria. However, further study can be carried out to cover West Africa or Sub-Saharan Africa for comparison purposes.

\section{Appendices}

\section{Appendix A: Table 1: Descriptive Results of Quantitative Variables}

\begin{tabular}{llcrl}
\hline Variables & Observations & Mean & Min. & Max. \\
\hline Enterprise age & 507 & 14.50 & 0 & 64
\end{tabular}


Bello O.F., Mustapha Y.I., KJM, 2021, 10 (01)

$\begin{array}{lllll}\text { Manager/owners } & 507 & 13.06 & 1 & 54\end{array}$

experience

Source: Authors' Compilation from Stata Printout

Appendix B: Table 2: Descriptive analysis of qualitative variables

\begin{tabular}{|c|c|c|c|}
\hline Variables & Observations & Frequency & Percentage \\
\hline Access to finance & 507 & 53 & 10.45 \\
\hline Owners/manager skill & 507 & 141 & 27.81 \\
\hline Owner's gender & 507 & 58 & 11.44 \\
\hline $\begin{array}{l}\text { Extent of foreign } \\
\text { ownership }\end{array}$ & 507 & 6 & 1.80 \\
\hline
\end{tabular}

Appendix C: Table 3: Robust Logistic Regression Results

\begin{tabular}{ll}
\hline Independent variables & Dependent variable = Access to finance \\
\cline { 2 - 2 } & \multicolumn{1}{c}{ Odds Ratio } \\
\hline Enterprise age & -0.990 \\
& $(-0.26)$ \\
Enterprise age squared & 1.000 \\
& $(0.19)^{*}$ \\
Foreign ownership (dummy) & 4.089 \\
& $(1.60)$ \\
Manager's/Owner's skill (dummy) & 2.040 \\
& $(2.31)^{* *}$ \\
Managers'/owners' experience & 1.035 \\
& $(2.00) * *$ \\
Owners/manager gender & 1.426 \\
& $(0.85)$ \\
Pseudo R & 0.034 \\
Wald chi-square & $12.14^{*}$ \\
Log pseudo likelihood & 164.038 \\
No. of observation & 507 \\
\hline
\end{tabular}

Source: Computed by the author from Nigeria Enterprise Survey 2014 dataset using Stata Version 14

Note: Significant at $10 \%(*), 5 \%(* *), 1 \%(* * *)$. The figures in parentheses are $\mathrm{z}$-values. 


\section{References:}

Afandi, E., \& Kerman, M. (2014). Financing obstacles of Bangladesh firms: Evidence from Pre-Crisis and Post-Crisis Periods Journal of Asian Economic and Finance Research, 4(9), 1158-1174.

Akande, O. O., \& Ojukuku, R. M. (2008). The impact of entrepreneurial skills on small business performance in Lagos-SouthWestern Nigeria. World Conference. Halifax, Nova Scotia:International Council for Small Business.

Akerlof, G. A. (1970). The market for lemons: Quality, uncertainty and the market mechanism. Journal of Economics, 84 (3), 353-374.

https://doi.org/10.2307/1879431

Akpotohw, F.C. (2007). Sustaining growth of SMEs through intervention programmes of government: problem and challenges. Journal of Business Studies and Technology, 2(4), 46.

Aryeetey, E., Baah-Nuakoh, A, Duggleby, T, Hettige, H \& Steel W.F. (1994). Supply and demand for finance of small-scale enterprises in Ghana, World Bank Discussion Paper No. 251, The World Bank, Washington, D.C.

Ayalew, B.B. \& Gashu, M. (2015). Factors affecting access to finance with reference to micro and small enterprises in Dilla town, Ethiopia. Journal for Studies in Management and Planning, 6(5), 32-53.

Beck, T., Dermirguc-kunt, A., Laeven, L. \& Maksimovic, V. (2006). The determinants of financing obstacles. Journal of International Monetary and Finance, 25(6), 932-952.

Chowdhury, M. and Alam, Z. (2017). Factors affecting access to finance of small and medium enterprises of Bangladesh. USV Annals of Economics and Public Administration, 2(26), 55- 68.

Essien U. A., \& Arene C. J. (2014) An analysis of access to credit markets and the performance of small scale agro-based enterprises in the Niger Delta region of Nigeria. International Journal of Food and Agricultural Economics, 2(3), 105-120.

https://doi.org/10.22004/ag.econ.186271

Fatoki O.O. \& Asah F. (2011). The impact of firms' characteristics on access to debt finance by SMEs in King Williams' Town South Africa. International Journal of Business and Management, 6, 170-179. https://doi.org/10.5539/ijbm.v6n8p170

Filli, F. B., Onu, J. I., Adebayo, E. F., and Tizhe, I. (2015). Factors Influencing Credits Access among Small Scale Fish Farmers in Adamawa State. Nigeria Journal of Agricultural Economics, Environment and Social Sciences, 1(1), 46-55.

Gamage, P. (2013). Determinants of access to Bank finance for small and medium-sized enterprises: the case of Sri Lanka. Corporate ownership and control, 10(3),402-409. https://doi.org/10.22495/cocv10i3c3art6

Ganzalo, T., Lopes, M \& Saunna, A. (2007) Spanish firms access to external financing. Journal of Business Studies and Technology, 4(2), 23-36.

Hailperm, S., \& Visintainer, P. (2003). Odd ratio and logistic regression: Further examples of their use and interpretation. The Stata Journal, 3(3), 121-132. https://doi.org/10.1177/1536867X03003003 01

Hamid, M.Y., \& Bello, K. (2008). The role of SMEs in poverty alleviation and development in Nigeria. Journal of Business Administration and Management, 2(4), 4-6

Harvie, C., \& Lee, B. (2008). Small and medium enterprises in East Asia. United Kingdom: Edward Edgar Publishing

Harvie, C., Narjoko, D. \& Oum, S. (2013). Small and medium enterprises access to finance: Evidence from selected Asian economies. ERIA Discussion paper series.154. DP-2013-23 
Kaino, T.M (2005). Rural credit market in Myanmar: A study of formal and nonformal lenders. Asian Journal of Agriculture and Development, 4(1), 3-15.

Kira R.A. (2013). The evaluation of the factors that influence the access to debt financing by Tanzania SMEs. European Journal of Business and Management, (5), $1-24$

Kraemer-Mbula, E., Lorenz, E., TakalaGreenish, L., Jegede, O.O., Garba, T., Mutambala, M., \& Esemu, T. (2019). Are African micro-and small enterprises misunderstood? Unpacking the relationship between work organisation, capability development and innovation. International Journal Technological Learning, Innovation and Development, 11(1), 1-30.

Kuranja, J.G., Nwangi, A.K., \& Nyakarimis, N. (2014). Analysis of the factors influencing access to credit services by women entrepreneurs in Kenya. Journal of inance and Accounting, 5(11), 65-82.

Kwaido, A. A., (2009). Women entrepreneurs and the development of smallscale enterprises in Sokoto metropolis. Unpublished M.Sc. Economics Dissertation, Usmanu Danfodiyo University, Sokoto, Nigeria.

Leiponen, A. (2005). Skills and innovation. International Journal of Industrial Organization,23(5-6), 303-323. https://doi.org/10.1016/j.ijindorg.2005.03.00 5

Lietner, S.M. \& Stehrer, R. (2013). Access to finance and funding composition during the crisis: A firm-level analysis of Latin American industry. Latin America Journal of Economics, 50(1), 1-20

Manyinka, J., \& Sinclair, J. (2012). Manufacturing the future: The next era of global growth and innovation. Mckinsey Global Institute. Retrieved from https:/www.mckinsey.co.
Marques, C.S., \& Ferreira, J (2009). SME innovative capacity, competitive advantage and performance in a traditional industrial region of Portugal. Journal of Technology Management \& Innovation, 4(4),17-26. https://doi.org/10.4067/S07187242009000400005

Martins, M.M. \& Daniel, K.T. (2013). Does firm profile influence financial access among small and medium enterprises in Kenya, Asian Economic and Financial Review, 3(6), 714-723.

Mersha, D. \& Zenhun, A. (2017) Determinants of access to formal financial sources of micro and small enterprises in west Oromia Region of Ethiopia. Journal of Business and Economics, 6(5), 101-110. https://doi.org/10.11648/j.ijber.20170605.13

Mustapha, Y.I., Anafi, O. A. \& Gbadeyan, R. A. (2014). Product diversification and performance of listed quoted food and beverage industry in Nigeria. AAU Annals of Accounting, Educational and Social Research. 1 (1); 45-62.

North, D., Robert, B., \& Ignatius, E. (2010). Is there a debt finance gap relating to Scottish SMEs? A demand side perspective? An International Journal of Entrepreneurial Finance, 12(3),173-192.

https://doi.org/10.1080/13691061003658670

Obitayo, K.M. (1991) Government industrial policies in respect of small and medium enterprises in Nigeria. Bullion 15(3), Abuja: Central Bank of Nigeria. OECD, (2005). Oslo manual: Guidelines for collecting and interpreting innovation data, (3rd ed.). Paris: Organisation for Economic cooperation and Development (OECD).

Ogubazghi, K.S. \& Muturi, W. (2014). The effect of age and educational level of owner/manager on access to loan in Eritrea: Evidence from Asmaras city. American Journal of Industrial and Business Management, 6(4), 632-643. 
Oum, S., Narjoko, D., \& Harvie, C. (2014). Constraints of SME innovation, and the role of government support. ERIA Discussion Paper Series, 2014-10 1-38.

Politis, D. (2008). Business angels and value added: What do we know and where do we go? An International Journal of Entrepreneurial Finance, 10(2), 127-147. https://doi.org/10.1080/13691060801946147

Raji, R. (2018). Manufacturing in Nigeria: Status, challenges and opportunities, NTUSBF Centre for African Studies.

Sebopetji. T.O. \& Belete, A. (2009). An application of probit analysis to factors affecting small scale farmers decision to take credit: A case study of Greater Letabo Local Municipality in North Africa. Journal of Agricultural Research, 4(8), 718-723.

Stiglitz, J. E., \& Weiss, A. (1981), Credit rationing in markets with imperfect information, American Economic Review, 71(3), 393-410.

Villalonga, B. (2014). Finance and Strategy, Emerald Group Publishing Limited. United Kingdom.https://doi.org/10.1108/S0742332220140000031012

World Bank (2017). International bank for reconstruction and development: The world bank group report $1818 \mathrm{H}$ Street NW, Washington DC 20433.

World Bank, (2012). Doing business in a more transparent world. WB, Washington

World Bank (2014). Nigeria Enterprise Survey 2014. Washington DC: The World Bank.

Zarook, T., Rahman.M.R. \& Khenam, R. (2013). Management skills and accessing to finance: Evidence from Libya SMEs. International Journal of Business and social sciences, 12(8), 106-115.
Zeller, M. (1994). Determinants of credit rationing: A study of informal lenders and formal credit groups in Madagascar. World Development, 22(12), 1895-1907. https://doi.org/10.1016/0305750X(94)90181-3 